\title{
Local Government in the 2013 Constitution of Zimbabwe: Defining the Boundaries of Local Autonomy
}

\author{
Tinashe Calton Chigwata ${ }^{1} \cdot$ Jaap de Visser $^{1}$
}

\begin{abstract}
The 2013 Constitution of Zimbabwe recognises local government as the lowest tier of government in a three tier arrangement. Thus, local government, composed by urban and rural local authorities, now owes its existence directly to the Constitution and not to legislation as was the case under the previous constitutional order. The Constitution assigns to local authorities the responsibility to 'manage' and 'represent' the affairs of people in their respective areas. Every local authority is given the 'right to govern' its jurisdiction with 'all' the necessary powers to do so, including devolved powers. Thus, the Constitution recognises that, for the benefits associated with decentralisation to be realised, local authorities require a certain measure of local autonomy. The autonomy which this Constitution affords to local government is however unknown and unexplored, especially from a constitutional law point of view. In this article, we measure the degree of local autonomy guaranteed by the 2013 Constitution.
\end{abstract}

Keywords Local government · Local autonomy · Constitution of Zimbabwe · Decentralisation - Devolution - Zimbabwe

\section{Introduction}

The role of local government is often underrated even though it is the level of government that often has the most significant contact with citizens. In many countries, local governments are responsible for the delivery of basic services such as water and electricity supply, refuse removal, sanitation and the regulation of land

Tinashe Calton Chigwata

tchigwata@gmail.com

1 Dullah Omar Institute, University of the Western Cape, Private Bag X17, Bellville 7535,

South Africa 
use. The role of local government sometimes extends to a wider range of services and may even include social functions such as education and health. ${ }^{1}$ While the responsibilities of local governments vary from country to country, there is no doubt that their functions critically impact the wellbeing of citizens. Over the past three decades, various international instruments and guidelines have acknowledged this important role of local government as well as the institutional design that is considered to be conducive for that role. ${ }^{2}$ These instruments and guidelines particularly emphasise the need to guarantee local government a certain minimum level of autonomy in order to maximise the potential to realise the benefits usually associated with decentralisation such as improved service delivery and deepened democracy. ${ }^{3}$

Zimbabwe, like many other developing countries, seeks to use decentralisation to facilitate development, democracy and national unity. The new Constitution ${ }^{4}$ adopted in 2013 recognises the role of local government in a three tier system of government. It seems to grant a certain level of autonomy to local authorities. In general terms, the Constitution requires devolution of power, responsibilities and resources to the local level. ${ }^{5}$ More explicitly, it guarantees the 'right to govern' of every local authority with 'all' the powers necessary to do so. ${ }^{6}$ The precise contours and limits to this local autonomy implied by the Constitution is however unknown and largely unexplored. In this article, we measure the degree of local autonomy afforded by the 2013 Constitution. The article is premised on the well-established notion that local governments play a key role in facilitating development, deepening democracy and preserving national unity and that a certain degree of local autonomy is necessary to facilitate that role. ${ }^{7}$

The first part of the article suggests a method for measuring local autonomy which is largely informed by international literature on decentralisation. This is followed by a brief discussion of the history of local government in Zimbabwe and a discussion of what the 2013 Constitution provides on local government. The article then proceeds to evaluate the degree of local autonomy in the Constitution and suggest legislative reforms where relevant. The objective is to contribute towards the process of constitutional implementation with a particular focus on local government. Finally, concluding remarks are then given.

\footnotetext{
1 For instance, the local government systems of Zimbabwe, South Africa and Uganda.

2 See the Africa Charter on the Values and Principles of Decentralisation, Local Governance and Local Development (adopted by the twenty-third ordinary session of the Assembly, held in Malabo, Equatorial Guinea, 27 June 2014); United Nations Human Settlement Programme (UN-Habitat) International guidelines on decentralisation and the strengthening of local authorities, UN-Habitat 2007, Nairobi; Council of Europe European Charter of Local Self-Government, Strasbourg, 15.X.1985; Commonwealth Local Government Forum, Time for local democracy, the Aberdeen Agenda: Commonwealth principles on good practice for local democracy and good governance, London, April 2005.

3 See World Bank (1999), pp. 107-108; Erk (2014), pp. 536-537; Chigwata (2015), pp. 442-443.

${ }^{4}$ Constitution of Zimbabwe, Amendment No. 20 of 2013.

5 See Preamble of Chapter 14, Section 264(1) Constitution.

6 See Section 276(1) Constitution.

7 See Panara (2013), p. 372.
} 


\section{Defining and Measuring Local Autonomy}

Local autonomy can generally be defined as the extent to which local governments have discretion in carrying out their duties and obligations. It does not connote freedom on the part of local authorities to take whatever decisions they want. Rather, it refers to a certain measure of discretion to make laws, adopt policies and take decisions within a framework of national or regional laws and subject to national and/or regional supervision. ${ }^{8}$ While there is no universally accepted list of features that constitute local autonomy, some basic features can be identified across the literature and international instruments on decentralisation. ${ }^{9}$

Firstly, local autonomy is reflected by the extent to which the existence of local units is guaranteed. Secondly, it is important to consider the functional areas allocated to local units and the discretion they have when exercising powers in those functional areas. Thirdly, local democracy is a basic feature of local autonomy. The fourth dimension relates to the revenue local units have access to and the discretion they have in spending them. Fifthly, local autonomy can be measured by assessing the discretion local units have with respect to their own bureaucracies. The sixth feature relates to the extent to which other levels of government may interfere in the exercise of local powers. These six features are discussed in more detail below.

\subsection{Security of Existence}

It is not uncommon for central governments to, in one way or another, extol the virtues of decentralisation and commit to protecting local government institutions. However, history tells us that the intention to decentralise power and resources to local level is not a sure enough guarantee that local government's existence is secure. ${ }^{10}$ Thus, some measure of protection of the existence of local government is vital. This is particularly important given that local governments are unlikely to perform effectively if their existence is put in constant jeopardy by the ability of higher governments to dis-establish, dismantle, merge or dissolve them at any time. ${ }^{11}$ Security of existence can be understood in two ways. First, the existence or importance of local governments as a tier, level or sphere of government can be secured or recognised, preferably, in the Constitution. Such constitutional recognition serves as a deterrent against executive or legislative invasion of local powers by higher government and provides a basis for judicial enforcement of constitutional limits. ${ }^{12}$ It is, however, of little relevance in a country where there is no respect for

\footnotetext{
8 Panara (2013), p. 371.

9 See Africa Charter on the Values and Principles of Decentralisation, Local Governance and Local Development; UN-Habitat, International guidelines on decentralisation and the strengthening of local authorities; Council of Europe European Charter of Local Self-Government; Commonwealth Local Government Forum, Time for local democracy, the Aberdeen Agenda: Commonwealth principles on good practice for local democracy and good governance; Panara (2013); Tarr (2011); Eaton and Schroeder (2010); World Bank (1999).

${ }^{10}$ Tarr (2011), p. 172.

11 Kalin (1998), p. 1.

12 Tarr (2011), p. 173.
} 
the constitution and/or where court judgments do not matter. It can also be easily evaded if there are no stringent procedures of amending the constitutional provisions protecting local government. Secondly, the existence of each individual local government unit, together with its legal status and political appearance can be secured. While constitutional protection of each local government unit is neither feasible nor practical, a constitution can include measures to guard against arbitrary disestablishment or amalgamation of local authorities.

In some countries on the African continent, the constitution not only guarantees local government as a level of government but also extends protection to each local government unit individually. For example, section 3(6) of the Constitution of Nigeria (1999) provides that there 'shall' be 768 Local Government Areas and six area councils in Nigeria. These local government areas and area councils are then listed by name in the First Schedule of the Constitution of Nigeria. This secures the existence of each local government unit. The disadvantage is that it is creates inflexible local boundaries. In practice, local government boundaries may need to be adjusted to changes in population, settlement and movements of people. Some constitutions therefore opt to recognise substantive and/or procedural criteria for changing local government boundaries. Such mechanisms, especially if coupled with the role of an independent body, have proved effective in providing security of existence to each local unit in countries such as South Africa. ${ }^{13}$

\subsection{Democracy}

Local democracy lies at the heart of decentralisation. In the context of local government, it means that voters are allowed to elect local representatives under a legal and institutional environment that guarantees regular, free and fair elections. Local autonomy loses meaning when local leaders are appointed by higher authorities. Local democracy also refers to citizens participating in decisions that affect them. The extent to which a constitution recognises this dimension to local democracy is important. Constitutional recognition of the values of participatory democracy and the establishment of participatory structures and mechanisms can go a long way in promoting a culture of participatory democracy. Accessibility and public disclosure of budgeting, procurement, and expenditure decisions and processes are a fundamental element of this. ${ }^{14}$

\subsection{Powers}

The constitutional protection of local powers provides the assurance that decentralised powers will not be recentralised arbitrarily. Further, if local governments are to play a meaningful role in facilitating development, their powers ought to be relevant to that. ${ }^{15}$ Therefore, it is important to asses not only whether or not powers

\footnotetext{
13 See Fessha and de Visser (2015), pp. 87, 90-92.

14 Ford (1999), p. 14.

15 World Bank (1999), p. 109. The assignment of functions to subnational governments can be based on considerations such as economies of scales, cost-benefit spill overs and proximity to beneficiaries.
} 
are guaranteed but also whether the powers are relevant. The principle of subsidiarity may serve as a useful benchmark to determine whether local governments are empowered to take charge of those functions that are capable of devolution. Furthermore, it is important that local powers are clearly demarcated to reduce overlap in responsibilities, cost-evasion, loss of accountability and unfunded mandates. ${ }^{16}$ In addition to being relevant and clearly demarcated, it is important to assess the extent to which the allocation of power involves discretion or final decision making authority. ${ }^{17}$ Panara argues that 'the existence of an autonomous sphere of responsibility is one of the essential elements of local [autonomy]. ${ }^{18}$ Circumstances (size, demographics, the local economy etc.) in local authorities differ. The same applies to their capabilities to deliver and finance public services. The model of decentralisation must thus be sensitive to such differences. ${ }^{19}$ A degree of asymmetry with respect to institutions and powers may be achieved, for example by recognising categories of local governments. ${ }^{20}$

\subsection{Revenue}

There is no doubt that the extent to which local governments have access to revenue determines, to a large degree, their success. The question as to whether local governments are empowered by law to raise their own revenue is a critical factor in assessing a multi-level government design. The principle that 'finance follows function'21 implies that local governments should have access to the finances commensurate to their responsibilities. Local taxing powers are likely to be of little relevance for revenue mobilisation and fiscal autonomy, if they are not accompanied by the right to set tax rates. The degree to which local governments control their own budgets and expenditure is a further determinant of local autonomy. ${ }^{22}$ While national governments may require a degree of oversight over local budgets to safeguard national interests, the power to reject a local budget diminishes fiscal autonomy of local decision makers. ${ }^{23}$ Hence, the recognition of local taxing powers and budget autonomy in the constitution is an important indicator of local autonomy. The design of the fiscal intergovernmental system to complement local resource-raising efforts is also important given the disparities that often characterise most jurisdictions.

\footnotetext{
16 Word Bank (1999), p. 124.

17 Kalin (1998), p. 2; Bahl (1999), p. 5.

18 Panara (2013), p. 379.

19 Ford (1999), p. 14.

20 Bahl (1999), p. 10.

21 Bahl (1999), p. 7, World Bank (1999), p. 124.

22 Budget autonomy also means that subnational governments do not carry out delegated responsibilities without commensurate resources_-see Eaton and Schroeder (2010), p. 180; Panara (2013), p. 376.

23 Eaton and Schroeder (2010), p. 180.
} 


\subsection{Administration}

Another important aspect of local autonomy is whether or not local governments have control over personnel and internal administrative processes. The authority over personnel, i.e. the ability to hire, fire and discipline staff frees local governments from reliance on higher levels of government and their bureaucracies to implement local policy decisions. ${ }^{24}$ If local governments are made dependent on centrally appointed staff, local bureaucrats may feel more accountable to central government than to the local leadership. Such authority should be accompanied by authority to determine as far as possible their own internal administrative structures, to adapt them to local needs and to ensure effective management. ${ }^{25}$ Guaranteeing this in the constitution is an important measure of the extent to which local governments can devise and administer policies within their respective jurisdictions. $^{26}$ There is a downside, however. Administrative autonomy increases the risk of elite capture at local level. ${ }^{27}$ It also increases the risk of inequitable distribution of skilled and qualified human resources between urban and rural jurisdictions. Mechanisms to address the downside of administrative autonomy are thus required, as explained in detail below.

\subsection{Extent of Supervisory Powers}

To empower national government to supervise local governments is as important as granting local governments autonomy. ${ }^{28}$ National supervision is necessary to address the challenges usually associated with decentralisation such as elite capture, capacity problems, regional inequality and threats to macro-economic instability. ${ }^{29}$ Supervision is understood here to refer to the power to regulate, monitor, support, and intervene in local affairs. With respect to regulation, the national government should be able to determine a national legal framework within which local governments must operate. It should also be legally permitted to monitor the performance of local governments as well as its compliance with the law. Regularised audits as well as obliging local governments to report regularly and openly on their financial status may serve to improve local governance.

When monitoring reveal challenges that hinder the ability of a local authority to perform its functions, it may be necessary for the national government to support that local authority. As a measure of last resort, national government should be able to intervene in a local authority that behaves illegally by assuming (parts of) its authority. This is the most intrusive form of supervision and whether or not it can co-exist with a system of decentralised government can only be assessed with reference to the checks and balances that surround this instrument. The arbitrary

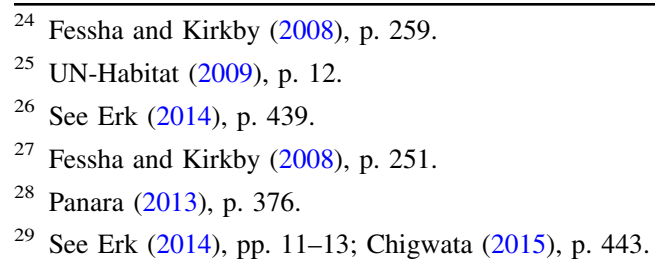


removal of locally elected officials or take-over of local functions will undermine the decentralised system of government. It is therefore important to assess whether there are procedural and substantive criteria for intervention and whether the intervention can be reviewed by an independent institution. Furthermore, the extent to which the rules for intervention are constitutionalised speaks volumes about the protection of local autonomy and the role of national government. ${ }^{30}$

By way of context to the assessment of local government in Zimbabwe in terms of the above indicators, a brief history of local government in Zimbabwe follows below.

\section{History of Local Government in Zimbabwe}

Local government has been a feature of governance in Zimbabwe since the colonial times. Before then, the institution of traditional leadership comprising kings, chiefs, headmen and village heads, was the only governance structure. ${ }^{31}$ During the colonial era, local government was racially organised. Urban councils were responsible for managing urban areas inhabited mostly by whites and rural councils administered only those parts of rural areas which were occupied also by whites. Other local institutions - advisory and town boards-were established to manage urban areas inhabited by blacks. The successive colonial governments exercised indirect rule over communal rural areas, where the majority of blacks resided, through the institution traditional leadership and native (African) councils. ${ }^{32}$ The urban and rural councils were well-resourced and had more powers that the local government structures established for blacks. This status quo largely remained intact until 1979 when the independence settlement was reached at Lancaster House between the liberation movements and the Rhodesian and British governments. The negotiated Lancaster House Constitution, which became the supreme law of independent Zimbabwe, did not recognise local government. It only recognised the role of traditional leaders. Local government was a creature of national legislation. This meant that its existence and form was determined by the national government. ${ }^{33}$ Classified into urban and rural local authorities, local government could only exercise those powers granted by ordinary legislation. The primary pieces of legislation are the Urban Councils Act ${ }^{34}$ and Rural District Councils Act. ${ }^{35}$

The Urban Councils Act and Rural District Councils Act assigned a range of responsibilities and powers to urban and rural councils, respectively. These responsibilities ranged from basic municipal services to welfare services, among others. Taxing powers were also decentralised to these local governments to enable them to fund the delivery of these services as well as meet other development

\footnotetext{
30 UN-Habitat (2009), p. 10.

31 Chigwata (2015), p. 445.

32 Chigwata (2015), p. 446-448.

33 See Mushamba et al. (2014), p. 5.

34 Chapter 29: 15 of 1996.

35 Chapter 29: 13 of 1988.
} 
priorities. The most prominent feature of both the Urban Councils Act and the Rural District Councils Act was that they both provided for a comprehensive scheme of supervision by the national government. The national minister responsible for local government was equipped with a wide array of powers that not only allowed him to set policy parameters but also to get involved in the day-to-day activities of local authorities. For instance, the Minister had the power to approve by-laws, budgets and plans before they could become operational or binding. ${ }^{36}$ The Minister could even rescind or alter decisions of the council. ${ }^{37}$ The exercise of national supervision has been quite controversial during the Lancaster House constitutional order, particularly since the Movement for Democratic Change (MDC), an opposition party, emerged on the scene in the early 2000s. Since then, the MDC has controlled most urban areas, including the biggest cities of Harare and Bulawayo, while the Zimbabwe African National Union-Patriotic Front (ZANU-PF) has maintained control of the national government. The central-local relations have been acrimonious ever since. Allegations of the Minister using his supervisory powers over local government for political gain are widely documented. ${ }^{38}$ Local autonomy was compromised in many ways. Some scholars trace the underperformance of local authorities to this excessive supervisory role of the Minister both in law and practice. $^{39}$

Under the Lancaster House constitutional order there was very little, if any, that prevented the central government from recentralising decentralised powers and responsibilities. Since independence, the national government has indeed recentralised a number of local responsibilities. For instance, the distribution of electricity, which used to be undertaken by selected urban local governments, was recentralised soon after independence. In 2005, the central government recentralised the water and sanitation functions and assigned them to a newly created parastatal, Zimbabwe National Water Authority. This was a failure, however, and the water and sanitation functions were restored to local government. ${ }^{40}$ In any event, the system of local government was premised on strict central control and very little, if any, autonomy for local authorities. During the process towards the adoption of the 2013, it became apparent that there was a desire to shield local government from politically motivated interventions. ${ }^{41}$ The 2013 Constitution therefore grants local authorities a certain degree of local autonomy. The remainder of this article focuses on how strong this autonomy is.

\footnotetext{
36 See Section 229(2), 219(1) Urban Councils Act and Section 90(4), 17(1) Rural District Councils Act.

37 See Section 314 Urban Councils Act and Section 52(3) Rural District Councils Act.

38 See Kamete (2006).

39 See Chakunda (2015), p. 4; Mushamba et al. (2014), p. 5, 10; Chigwata (2017), p. 222.

40 Mushamba (2010), p. 109.

41 Muchadenyika (2015), p. 111.
} 


\section{The Constitutional Basis of Local Government in Zimbabwe}

The 2013 Constitution organises government at the national, provincial and local levels. Provincial and metropolitan councils make up the provincial tier while the local tier of government is constituted by urban and rural local authorities. ${ }^{42}$ Urban local authorities are established to manage and represent the affairs of people living in urban areas, whereas rural local authorities govern rural areas. The Constitution permits the establishment of different classes of urban and rural local authorities. This system is designed to result in asymmetric decentralisation. ${ }^{43}$ This constitutional provision is an acknowledgement of the differences between rural and urban areas and the local authorities there.

Contrary to the previous constitutional dispensation, the 2013 Constitution envisages local authorities exercising devolved powers and not only delegated powers. The principle of devolution is one of the Founding Values and Principles of the Constitution. ${ }^{44}$ It is further anchored by the Preamble of Chapter 14 which reads:

Whereas it is desirable to ensure: (a) the preservation of national unity in Zimbabwe and the prevention of all forms of disunity and secessionism; (b) the democratic participation in government by all citizens and communities of Zimbabwe; and (c) the equitable allocation of national resources and the participation of local communities in the determination of development priorities within their areas; there must be devolution of power and responsibilities to lower tiers of government in Zimbabwe.

The Preamble itself contains a constitutional instruction to the national government to devolve power to lower level governments in order to realise certain goals. Section 264(1) of the Constitution further gives effect to the Preamble by stating that 'whenever appropriate', the national government must devolve powers and responsibilities to local authorities 'which are competent' to carry out those responsibilities 'efficiently and effectively'. ${ }^{45}$ The obvious challenge with this provision is how to determine when it is 'appropriate' to devolve power or when a local authority is 'competent' to carry responsibilities efficiently and effectively. Given that the Constitution does not specify who decides when it is 'appropriate', it stands to reason that the national government will make that decision.

The Constitution lists six objectives of devolution:

(a) to give powers of local governance to the people and enhance their participation in the exercise of the powers of the State and in making decision affecting them;

(b) to promote democratic, effective, transparent, accountable and coherent government in Zimbabwe as a whole;

\footnotetext{
42 Section 5 Constitution.

43 See Section 274(3), 275(3) Constitution.

44 Section 3(2)(1) Constitution.

45 Section 264(1) Constitution.
} 
(c) to preserve and foster the peace, national unity and indivisibility of Zimbabwe;

(d) to recognise the right of communities to manage their own affairs and to further their own development;

(e) to ensure the equitable sharing of local and national resources; and

(f) to transfer responsibilities and resources from the national government in order to establish a sound financial base for each provincial and metropolitan council and local authority. ${ }^{46}$

The objective to 'recognise the right of communities to manage their own affairs and to further their development' is particularly important. It envisages further devolution of powers and responsibilities to local authorities. ${ }^{47}$ The objectives of devolution are supported by a set of general principles which are designed to regulate the conduct of local authorities. Local authorities are required to:

(a) ensure good governance by being effective, transparent, accountable and institutionally coherent;

(b) assume only those functions conferred on them by th[e] Constitution or an Act of Parliament;

(c) exercise their functions in a manner that does not encroach on the geographical, functional or institutional integrity of another tier of government;

(d) cooperate with one another, in particular by (i) informing one another or, and consulting one another on, matters of common interest (ii) harmonising and coordinating their activities;

(e) preserve the peace, national unity and indivisibility of Zimbabwe;

(f) ensure the fair and equitable representation of people within their areas of jurisdiction. $^{48}$

These principles regulate both the ways in which local authorities carry out their activities as well as the outcome of those activities. For instance, the duty to ensure good governance is an outcome while that of cooperating with one another is a means to an end-the end being effective multilevel governance. However, the principles are of little use to realise the intended outcome unless relevant laws and policies are enacted to give effect to them.

The requirement for and objectives of devolution as well as the principles of local government discussed above point to a minimum level of autonomy that local authorities must enjoy. Local authorities are yet to enjoy such autonomy partially because the legislation, which governs and impacts on local government, has not been reformed.

\footnotetext{
46 Sction 264(2) Constitution.

47 Mushamba et al. (2014), p. 5.

48 Section 265(2) Constitution.
} 


\section{Measuring the Degree of Local Autonomy in the 2013 Constitution}

The following assessment of the autonomy for local government in the 2013 Constitution is carried out on the basis of the indicators that were discussed in paragraph 2 above. It is argued that while the Constitution has identified local government as one of the key actors in development and democracy it contains few guarantees for local autonomy.

\subsection{Establishment and Disestablishment of Local Government}

The 2013 Constitution provides some recognition for local government by entrenching it as the lowest tier of government. ${ }^{49}$ At a minimum, this means that the national government may not modify the general status of local government as a tier of government without amending the Constitution. ${ }^{50}$ However, there is no constitutional protection for individual local authorities. ${ }^{51}$ The Constitution does not deal with the process or criteria for the establishment or disestablishment of local authorities and leaves this to Parliament to regulate. In terms of the current Urban Councils Act and Rural District Councils Act, the national government has wide powers to establish, abolish, merge or alter boundaries of a local authority(s) at any time. ${ }^{52}$ The affected local authority and its communities are consulted in the process of abolition, merger and establishment of local authorities but it is the national executive that makes the final decision. ${ }^{53}$ Furthermore, there is little, if any, scrutiny by Parliament or any independent body. It is argued that, with little or no oversight, there is ample room for these processes to be used for political ends.

\subsection{Election and Removal from Office of Local Officials}

With respect to the democratic status of local politicians, the 2013 Constitution deepens local democracy and thus supports an important aspect of local autonomy. This is borne out, firstly, by the objectives of devolution which include the promotion of democratic government in Zimbabwe. ${ }^{54}$ This means that governance structures and procedures should uphold and promote both representative and participatory democracy. Secondly, the constitutional guarantees for the election of local officials are important in this respect.

\subsubsection{Election of Local Officials}

The 2013 Constitution requires 'all' councillors of each local authority to be directly elected by registered voters within its area of jurisdiction. ${ }^{55}$ This is a departure from

\footnotetext{
${ }^{49}$ Section 5 Constitution.

50 Mushamba et al. (2014), p. 6.

51 See Mushamba et al. (2014), p. 5.

52 See section 4, 5, 6 Urban Councils Act and section 6, 8 Rural District Councils Act.

53 See section 9 Rural District Councils Act.

54 Section 264(2)(b) Constitution.

55 Section 265(2) Constitution.
} 
the previous constitutional order where some councillors were elected while others where appointed by the national Minister responsible for local government. ${ }^{56}$ These appointed officials carried out the same duties and were entitled to the same benefits as elected councillors, but could not vote in council meetings. ${ }^{57}$ The appointment of councillors by the Minister was not only undemocratic but also used to achieve political goals. ${ }^{58}$ A study carried out by De Visser and Mapuva in 20 major urban local authorities showed that out of 57 appointed councillors in these authorities only 2 were affiliated to the MDC while the rest were aligned to ZANU-PF. ${ }^{59}$ This clearly indicates there was tension between the notion of democratically elected councils and the central appointment of ministerial representatives to councils. By allowing elected councillors only, the 2013 Constitution thus seeks to break with this practice and thus deepens local democracy. The result of this new constitutional provision is that the current section 4A of the Urban Councils Act and section 11 of the Rural District Councils Act, both of which provide for the combination of elected and appointed councillors, are unconstitutional. ${ }^{60}$

\subsubsection{Removal from Office of Local Officials}

Under the previous constitutional order, the President could suspend and dismiss any councillor in a rural local authority from exercising all or any of their functions if he or she considered it 'necessary or desirable to do so in the public interest or in the interest of the inhabitants of a council area'. ${ }^{61}$ In urban local authorities, the Minister could also suspend and dismiss councillors on a number of grounds, including corruption or misconduct. ${ }^{62}$ These powers were exercised controversially, especially in urban local authorities. ${ }^{63}$ Between 1999 and 2008, the Minister suspended and/or dismissed a considerable number of councillors and/or councils on varying allegations of poor performance, 'shady' tendering procedures, corruption, mismanagement and incompetence. ${ }^{64}$ Most of the councillors or councils that were suspended and/or dismissed were aligned to the MDC, while the incumbent Minister was aligned to ZANU-PF. ${ }^{65}$ Arbitrary though the suspensions and dismissals may seem to be, the Minister relied on his powers under the Urban Councils Act. ${ }^{66}$

It is as a result of these challenges that the 2013 Constitution tried to reform the supervisory mechanism in relation to the suspension and dismissal of locally elected officials. Under the new constitutional regime, locally elected officials may no

\footnotetext{
56 See Section 11 Rural District Councils Act and Section 4A Urban Councils Act.

57 Mushamba (2010), p. 103.

58 Sims (2013), p. 17.

59 See De Visser and Mapuva (2013), pp. 170-171.

60 Section 31 of the Rural District Councils Act requires similar alignment.

61 Section 157(1)(2) Rural District Councils Act.

62 Section 114 Urban Councils Act. See also section 107, 108 and 109 Urban Councils Act.

63 Kamete (2006), p. 38.

64 Kamete (2006), p. 36.

65 Chakunda (2015), p. 4.

66 Kamete (2006), p. 38; Chakunda (2015), p 4.
} 
longer be removed from office arbitrarily. Section 278(1) of the Constitution now strictly regulates when a councillor vacates office. A councillor vacates office when he or she resigns, when the council is dissolved or if he or she ceases to be a qualified as a voter. ${ }^{67}$ A council, by majority decision, may also declare a council seat vacant if the incumbent was absent from the council for 21 consecutive days. The other grounds are: if a councillor accepts public office elsewhere or if he or she fails to relinquish that office after being elected as a councillor. Finally, the seat becomes vacant if the councillor is convicted of a crime. The Constitution now provides an exhaustive list of grounds for vacating office and this provision can be used as a basis for judicial review.

A councillor may also be removed from office by an independent tribunal provided for under an Act of Parliament. The grounds for removal are limited. The first group of grounds relate to inability to perform the functions of a councillor due to mental or physical incapacity, gross incompetence and gross misconduct. Furthermore, the tribunal may remove a councillor from office if he or she is convicted of an offence involving dishonesty, corruption or abuse of office. Wilful violation of the law, including a by-law, also constitutes a ground for removal. ${ }^{68}$ The decisions of the tribunal are reviewable by the High Court. It is suggested that the introduction of an independent body and the listing of specific grounds upon which locally elected officials may be removed from office provides protection to locally elected officials that they did not enjoy before. However, much will depend on how the Tribunal is constituted and whether it will be able to operate independently. As will be argued below, this is where the Constitution is being undermined by statutory law.

The Local Government Laws Amendment Act of 2016 was adopted to implement these constitutional provisions. It makes provision for the establishment of a three member independent tribunal to be established on an ad hoc basis. ${ }^{69}$ All the members of the tribunal, including its chairperson, are appointed by the Minister responsible for local government. The Law Society of Zimbabwe nominates individuals for the position of chairperson and the Civil Service Commission does the same with respect to the two other members of the tribunal. The head of the Ministry responsible for local government must provide administrative support to the tribunal. ${ }^{70}$ Thus, the Ministry responsible for local government plays a significant role in the establishment and functioning of this tribunal. In a cunning, but arguably unconstitutional move, the Act brings the Minister back as the prime overseer of councillors at the expense of the new Tribunal. It does this by stipulating that the Tribunal is only competent to consider the dismissal of councillors who have already been suspended by the Minister. ${ }^{71}$ The Act thus creates a distinction between suspension and dismissal. The first is the prerogative of the Minister and the second is the prerogative of the Tribunal. What is more, the Tribunal's power to

\footnotetext{
67 Section 129 Constitution.

68 Section 278(2) Constitution.

69 Section 157A Local Government Laws Amendment Act, 2016.

70 See section 2, 3 Local Government Laws Amendment Act, 2016.

71 See section 2(3) Local Government Laws Amendment Act, 2016.
} 
dismiss is made conditional upon the Minister first having suspended that councillor. It is argued that this condition makes it impossible for the Tribunal to exercise its power independently of the Minister. Instead, the Act limits the Tribunal's power to a power to 'consummate' a suspension that was initiated by the Minister by turning it into a dismissal. This, it is submitted, goes against the provisions of the Constitution. While the Constitution offers considerable protection to locally elected officials, the Local Government Laws Amendment Act undermines this.

It then also comes as no surprise that controversial suspensions of councillors continued after the adoption of the 2013 Constitution. Since then a number of councillors from Gweru, Harare and Bulawayo have been suspended under disputed circumstances. ${ }^{72}$ In separate cases, the Gweru and Harare councillors challenged the constitutionality of their respective (re)suspensions. The Court declared the (re)suspensions illegal and directed their reinstatement. ${ }^{73}$ It is argued that the constitutional and legal framework provides insufficient protection against the suspensions and dismissals of locally elected officials, orchestrated for political gain.

\subsection{Powers and Responsibilities of Local Authorities}

As indicated earlier, the extent and scope of powers for local authorities is an important indicator of local autonomy. With respect to this, the new Constitution presents a mixed picture. Section 276(1) of the Constitution states that 'subject to th[e] Constitution and any Act of Parliament, a local authority has the right to govern, on its own initiative, the local affairs of the people within the area for which it has been established, and has all the powers necessary for it to do so' ${ }^{74}$ With this provision, which closely resembles section 151(4) of the South African Constitution, the Constitution itself seems to allocate powers directly to local authorities. It affords a constitutional 'right' to each local authority to govern the affairs of its people. However, this right can be limited not just by the Constitution (as is the case in the South African equivalent to this section) but also by any Act of Parliament. This then significantly reduces the constitutional protection offered by this provision. The Constitution does not list the powers and functions of local authorities. A system of 'enumerated powers would provide some degree of certainty as to what local authorities can and/or shall do' ${ }^{75}$ Instead, the Constitution gives Parliament the discretion to determine local powers and functions through legislation. ${ }^{76}$ The implication of the lack of constitutional recognition of the powers

\footnotetext{
72 See Hamutendi Kombayi and Ors $v$ The Minister of Local Government, Public Works and National Housing and Ors HB 57116; Manyenyeni v Minister, Local Government, Public Works and National Housing \& Another (HH 385-16 HC 5903/16) [2016] ZWHHC 385 (29 June 2016).

73 See Hamutendi Kombayi and Ors $v$ The Minister of Local Government, Public Works and National Housing and Ors; Manyenyeni v Minister, Local Government, Public Works and National Housing \& Another.

74 Section 276(1) Constitution.

75 Panara (2013), p. 383.

76 Section 276(2) Constitution.
} 
and functions of local authorities is that the national government may recentralise them at any time. As observed above, such recentralisation has been common in Zimbabwe.

However, it cannot be argued that the 2013 Constitution did not change anything.

Given that it affords every local authority 'the right to govern' and 'all' the powers necessary to do so, it requires that local authorities exercise significant powers and enjoy a certain measure of local autonomy. It is suggested that, at a minimum, it means that there are limits to the role of national government in local affairs. Effective protection and promotion of such as 'right' requires that the excessive supervisory powers which were assigned to the Minister under the Lancaster House Constitution (such as the power to reverse, suspend and alter council resolutions) be reformed. ${ }^{77}$ Furthermore, it suggested that it also means that the national government is under a constitutional obligation to decentralise relevant and significant powers in line with the principle of subsidiarity.

\subsection{Revenue-Raising at Local Level}

Local authorities in Zimbabwe generally raise revenue by charging user fees, imposing taxes or accessing grants from the national government. One of the objectives of devolution in the Constitution is 'to transfer responsibilities and resources from the national government in order to establish a sound financial base for each provincial and metropolitan council and local authority'. ${ }^{78}$ The Constitution recognises how important financial resources are for the ability of local authorities to effectively perform their functions. The question is, however, whether the Constitution goes further than this general objective. To what extent does it guarantee local authorities access to revenue?

\subsubsection{Taxing Powers}

The Constitution does not assign specific powers to raise revenue to local authorities. However, it does provide a general framework and clearly envisages the assignment of revenue-raising powers to local authorities so as to establish a sound financial base for each local authority. ${ }^{79}$ It provides that an 'Act of Parliament may confer functions on local authorities, including the power to levy rates and taxes and generally to raise sufficient revenue for them to carry out their objects and responsibilities' ${ }^{80}$

The Urban Councils Act, Rural District Councils Act and other sectoral pieces of legislation assign to local authorities the power impose user-charges, property tax, levies, licencing fees and the authority to sell or lease land or buildings. ${ }^{81}$ However,

\footnotetext{
77 See Mushamba (2010), p 107.

78 Section 264(2)(f) Constitution.

79 See Section 264(2) Constitution.

80 Section 276(2)(b) Constitution.

81 See Section 218, 159, 179, 173, 174, 178, 152, 269, 272; Second Schedule 12, 17; Urban Councils Act and Section 72, 75, 86, 96, 97, 98 Rural District Councils Act.
} 
they prohibit a local authority from raising user-charges without the permission of the Minister. ${ }^{82}$ Not having the final say over the determination of tax rates means that local authorities are unable to vary rates in line with local economic developments to improve revenue mobilisation. Furthermore, despite having revenue-raising powers, local authorities actually raise very little revenue. ${ }^{83}$ Two decades of economic hardship has adversely impacted the ability of citizens and the business community to pay for services provided. The taxing powers that local authorities do control are also not the most buoyant: income tax, company taxes, toll fees and vehicle related taxes are all reserved for national government. ${ }^{84}$

Sims therefore argues that the failure by the Constitution to guarantee the financial autonomy of local authorities will perpetuate the marginalisation of local authorities that have 'stunted local development since independence'. ${ }^{85}$ It is submitted that the constitutional objective to establish a sound financial base for each local authority must require the decentralisation of taxes to local level. Revenue sources that are capable of raising significant revenue for local authorities must be transferred together with a degree of discretion in determining taxation rates. The exercise of local autonomy must be supervised by the national government. However, the role of the Minister should be limited to setting a national framework for each local authority to exercise its powers to determine rates with respect to relevant and reasonably buoyant taxes and fees. This would go a long way in ensuring that local authorities become more self-sufficient. ${ }^{86}$

\subsubsection{Intergovernmental grants}

In any decentralised system, there will be a mismatch between local expenditure needs and the revenue generated locally. ${ }^{87}$ Moreover, each local authority's tax base and capacity to actually raise revenue will be different. Intergovernmental grant funding must thus complement the local revenue-raising effort. Revenue raised nationally must be shared among governments at various levels. The 2013 Constitution recognises the need for vertical and horizontal sharing of nationally generated revenue. The vertical division of revenue distributes portions of nationally generated revenue to the three tiers generally. The horizontal division determines what each individual local authority receives.

On the vertical division, the Constitution requires the allocation of 'not less than five per cent of the national revenues raised in any financial year' to provincial and local governments. ${ }^{88}$ This requirement does not guarantee any individual local

\footnotetext{
82 Section 219(1) Urban Councils Act and Section 17(1) Rural District Councils Act. The same requirements apply in respect of services provided specifically to or in connection with any residential accommodation.

83 Chigwata (2017), p. 226.

84 See Mushamba (2010), p. 111.

85 Sims (2013), pp. 23, 2.

${ }^{86}$ See UN-Habitat (2009), pp. 8-9.

87 See Bahl (1999), UN-Habitat (2009), Ford (1999).

${ }^{88}$ Section 301(3) Constitution.
} 
authority any specific amount or percentage but guarantees at least five per cent for the entire provincial and local sector. Cementing a minimum allocation to the provincial and local tiers in the Constitution inserts a degree of predictability into the intergovernmental fiscal system and must result in financial resources being channelled to provinces and local authorities. ${ }^{89}$ However, the percentage is too low to guarantee ten provincial governments and 92 local governments sufficient resources. Furthermore, the fact that the guarantee applies to both local and provincial governments combined does not augur well for local government. Local authorities require significant financial resources as they are expected to deliver public services. The functions of provincial governments are uncertain at best. Moreover, these provincial governments are to be constituted by a majority of officials from the national government and may be overseen by nationally appointed officials. This gives them greater leverage with national government. Thus, local authorities may lose out to provinces.

With respect to the horizontal division, the Constitution does not provide a specific formula to determine what each local authority receives. Section 301(1) of the Constitution directs Parliament to enact a law providing for conditional and unconditional grants to provincial and local governments. The allocation of such grants should be informed by criteria set in the Constitution. These include matters such as the consideration of national interests, the redistribution of wealth and economic resources between jurisdictions and disparities. ${ }^{90}$ The criteria resemble in many respects the criteria for the sharing of revenue among the three spheres of government provided in the South African Constitution. ${ }^{91}$ If they are implemented well, the intergovernmental fiscal system may be effective in addressing disparities among subnational jurisdictions. In summary, it is submitted that the national government must develop, in a transparent and consultative way, an equitable and predictable formula for both the vertical and horizontal sharing of revenue informed by the criteria of section 30(1) of the Constitution.

\subsubsection{Control Over the Budget and Expenditure}

The degree of control, exercised by higher authorities with respect to local budget decisions, is another important indicator of autonomy. This form of control is capable of considerably limiting the autonomy of local government. It can be used by higher tiers of government to by-pass the preferences of local citizens and impose their own political agenda. ${ }^{92}$

The 2013 Constitution does not explicitly grant local authorities the power to adopt their own budgets. However, it does anticipate local authorities exercising a variety of governmental powers, which can be argued to include budget powers. Section 276(2)(a) states that legislation may confer functions on local authorities for the effective administration of their respective jurisdictions. Moreover,

\footnotetext{
89 See UN-Habitat (2009), p. 9.

90 See Section 301(2) Constitution.

91 See Section 214 Constitution of South Africa, Act No. 108 of 1996.

92 Panara (2013), p. 385.
} 
section 276(1) which guarantees every local authority the 'right to govern, on its own initiative, the local affairs of its people,' with 'all' the necessary powers to do so, implies a degree of budget autonomy. The words on 'its own initiative' suggest that local authorities are expected to make expenditure decisions within the limits of the law. ${ }^{93}$ That said, it will be hard to argue that the Constitution unequivocally protects the power of each local authority to adopt its own budget.

\subsection{Administrative Autonomy at the Local Level}

The local government system in Zimbabwe empowers the national government to exercise direct control over local personnel issues. ${ }^{94}$ For example, section 132 of the Urban Councils Act demands the approval of the Local Government Board for the appointment of the town clerk. This interference has made it difficult for local authorities to adjust their respective personnel establishment to local or/and economic needs. ${ }^{95}$ A degree of constitutional protection for local authorities to make their staffing decisions would have been welcomed by those who argue that the national government often abuses these powers. However, the administrative autonomy of local authorities, i.e. their powers to hire and fire staff is not explicitly guaranteed in the Constitution. Section 276, discussed above, provides for generic powers to administer but this is made subject to the Constitution and national legislation. Section 279 also states that legislation must provide for the procedure to be followed by councils of local authorities. ${ }^{96}$ Both provisions suggest that national government will determine the precise contours of local administrative autonomy in ordinary legislation. It is submitted, however, that the constitutional entrenchment of local government and the adoption of the constitutional principle of devolution must shape the interpretation of section 276 of the Constitution. This provision guarantees local authorities a certain measure of administrative autonomy given its importance to effective governance. Arguably, the 'right to govern' includes the power to appoint and fire personnel as well as to determine internal administrative procedures. Similarly, the term 'on its own initiative' assumes that a local authority should be able to make individual decisions to hire and fire personnel within a framework determined by the national government. Moreover the Constitution allocates to local authorities "all" the powers necessary to "govern" whether with respect to personnel establishment or the determination of internal administrative procedures.

The City of Harare adopted this interpretation of section 276 when it appointed James Mushore as its town clerk in 2016. Contrary to section 132 of the Urban Councils Act, the City did not seek the approval of the Local Government Board. It argued that it has full authority under the Constitution to make the appointment. The national government responded by issuing a directive purportedly rescinding the appointment of Mushore as town clerk. The City and civic groups have since

\footnotetext{
93 See Panara (2013), p. 391.

94 Mushamba et al. (2014), pp. 10, 15.

95 See World Bank (1999), p. 120.

96 Section 279 Constitution.
} 
brought a High Court application, petitioning the Court to clarify the powers local authorities enjoy under the Constitution with regard to appointment of staff. If the City's approach is upheld, the provisions of the Urban Councils Act and Rural District Councils ${ }^{97}$ providing for interference by the Local Government Board or the Minister in staffing decisions, will have to be revisited.

In summary, while there is no explicit constitutional protection for local administrative autonomy, the Constitution contains provisions that suggest that there are limits to the extent to which national government may interfere in staffing decisions.

\subsection{The Supervision of Local Authorities}

Supervision, as argued in paragraph 2.6, is a 'reflection of the fact that, albeit endowed with [local] autonomy, a local authority is not a sovereign entity and is part of the overall state machinery'. ${ }^{98}$ Thus, the supervision of local governmentthrough regulation, monitoring, support and intervention-is a necessary component of the decentralisation regime. The question is whether the 2013 Constitution provides for the supervision of local authorities. National supervision of local authorities is necessary in order to combat corruption and minimise the wastage of resources. The Constitution requires the Parliament to supervise public debt, finances, and the use of borrowing powers by all government including, local authorities. ${ }^{99}$ Parliament also has an obligation to 'monitor and oversee' expenditure by local authorities and to enact legislation to give full effect to its financial oversight role. The Constitution also establishes the office of the Auditor-General to audit the accounts, financials systems and financial management of local authorities, among other duties. ${ }^{100}$

These two supervisory roles are reasonably clear and constitute critical features of the decentralisation design. However, the Constitution leaves a gap when it comes to the executive supervision by the national government. There is nothing in the Constitution that provides for the supervision of local authorities by the national or provincial government. This means, therefore, that there are also no explicit constitutional limits on the use of supervisory powers. ${ }^{101}$ There is then a risk that local authorities are not treated equally when it comes to the national executive supervising local government. This is all the more pertinent in a local government environment that is politically charged and where the ruling party at national government level is different from the party that controls key local government institutions. This has been the case in Zimbabwe since $2000{ }^{102}$

\footnotetext{
97 These are: section 132, 133, 134, 116, 123, 128, 129, 130 Urban Councils Act; Section 66 Rural District Councils Act.

98 Panara (2013), p. 383.

99 Section 299(1) Constitution.

100 Section 309(2) Constitution.

101 Sims (2013), p. 13.

102 Mushamba et al. (2014), p. 10; Chigwata (2017), p. 222.
} 
Current local government legislation equips the national Minister responsible for local government with virtually unlimited supervisory powers. These powers are often used excessively, raising concerns among scholars about the abuse of supervision powers for political ends. ${ }^{103}$ In fact, the toxic central-local relationship is often cited as one of the reasons why the local government system is failing to deliver basic services. ${ }^{104}$ At the same time, the excessive supervision by the Minister was almost done in line with the law, which gave the Minister extensive supervision powers. ${ }^{105}$

The drafters of the Constitution had the opportunity to clarify central-local relationships and, in particular, specify the scope of supervision powers. However, the Constitution leaves this to Parliament to regulate. It can be argued, again, that the constitutional principle of devolution and the constitutional 'right to govern' of local authorities must be interpreted to limit Parliament's discretion in regulating the supervision of local government. Parliament must strike a balance between the need for supervision and need for local autonomy. It is submitted that the extensive supervisory powers of the Minister responsible for local government, which were designed under the now repealed Lancaster House constitutional order, must be revisited.

\section{Conclusion}

This article set out to assess the autonomy afforded to local government under the 2013 Constitution of Zimbabwe. It was argued that the Constitution protects locally elected officials from being suspended or dismissed arbitrarily by the national government. However, the national legislation that was adopted to give effect to this protection contains provisions that go against this. Aside from the reasonably clear provisions that protect local democracy, the Constitution actually does not provide many hard rules guaranteeing the other basic features of local autonomy. The Constitution merely provides generic powers and functions of local government, the detail of which will depend on national legislation. It does not specify revenue raising powers and also does not limit the supervision of local authorities by the national executive. However, the intent to devolve power, responsibilities and resources is a prominent feature of the Constitution. Combined with the sacred phrase, in section 276 of the Constitution, that local authorities have 'the right to govern' there is scope for the argument that a degree of local autonomy is in fact protected by the Constitution. Much will depend on how the courts will interpret section 276 of the Constitution.

At the time of writing, the legislative regime for local government had not yet been brought in line with the Constitution, barring a few minor changes. The virtually unrestrained supervisory powers afforded to the national governments remain in place. This brings into question the commitment towards the establishment of a decentralised system of government under which local authorities enjoy

\footnotetext{
103 Muchadenyika (2015), p. 125; Mushamba et al. (2014), p. 10.

104 See Chakunda (2015), p. 4.

105 See Mushamba (2010), pp. 113-116; Chakunda (2015), p. 1.
} 
the degree of local autonomy necessary to reap the benefits associated with decentralisation.

\section{References}

Bahl R (1999) Implementing rules for fiscal decentralisation. International Studies Program Working Paper 99-1. https://www.gtac.gov.za/Event_Documents/Implementation\%20Rules\%20For\%20 Fiscal\%20Decentralization\%20Roy\%20Bahl.pdf. Accessed 10 Oct 2016

Chakunda S (2015) Central-local government relations: implications on the autonomy and discretion of Zimbabwe's local government. Political Sci Public Aff 3(1):1-4

Chigwata TC (2015) Decentralization in Africa and the resilience of traditional authorities: evaluating Zimbabwe's track record. Reg Fed Stud 25(5):439-453

Chigwata TC (2017) Fiscal decentralisation: constraints to revenue-raising by local government in Zimbabwe. In: Schoburgh E, Ryan R (eds) Handbook of research on subnational governance and development. IGI Global, Hershey, pp 218-240

De Visser J, Mapuva J (2013) Special interest councillors in Zimbabwe: reviewing law and practice in terms of the 2013 constitution. Law Democr Dev 1:157-176

Eaton K, Schroeder L (2010) Measuring decentralisation. In: Eaton K, Connerly E, Smoke P (eds) Making decentralisation work: democracy, development and security. Lynne Rienner Publishers, Boulder, pp 167-190

Erk J (2014) Federalism and decentralization in Sub-Saharan Africa: five patterns of evolution. Reg Fed Stud 24(5):535-552

Fessha Y, de Visser J (2015) Drawing non-racial, non-ethnic boundaries in South Africa. In: Steytler N, Pal-Ghai Y (eds) Kenya-South Africa dialogue on devolution. Juta, Claremont, pp 81-101

Fessha Y, Kirkby C (2008) Critical survey of subnational autonomy in African States. Publius 38(2):248-271

Ford J (1999) Constitutional, legal, and regulatory framework for decentralisation. In: Litvack J, Seddon J (eds) Decentralisation briefing notes. World Bank Institute, Washington DC

Kalin W (1998) What makes decentralised government work? Lessons from Switzerland. Essays Const Law 27:1-19

Kamete YA (2006) The return of the jettisoned: ZANU-PF's crack at 're-urbanising' in Harare. J South Afr Stud 32(2):255-271

Muchadenyika D (2015) The inevitable devolution in Zimbabwe: from constitution-making to the future. In: De Visser J (ed) Constitution-building in Africa. Community Law Centre: University of the Western Cape, Bellville, pp 119-139

Mushamba S (2010) The powers and functions of local government authorities. In: De Visser J, Steytler $\mathrm{N}$, Machingauta N (eds) Local government reform in Zimbabwe: a policy dialogue. Community Law Centre: University of Western Cape, Bellville, pp 101-138

Mushamba S, Bhoroma L, Chirisa I, Chaumba A (2014) The dynamics of devolution in Zimbabwe: a briefing paper on local democracy. Action Aid Denmark, Harare

Panara C (2013) Conclusion: the constitution of local self-government to constitutionalism in the member states and in the EU multi-layered system of governance. In: Panara C, Varney M (eds) Local government in Europe: the 'fourth level' in the EU multi-layered system of governance. Routledge, London, pp 387-413

Sims MB (2013) Conceptualising local government: local perceptions on devolution and participation in Zimbabwe. http://www.academia.edu/3536324/Conceptualising_Local_Government_Local_Percep tions_on_Devolution_and_Participation_in_Zimbabwe. Accessed 25 July 2014

Tarr AG (2011) Symmetry and asymmetry in American federalism. In: Courchene JT, Allan RJ, Leuprecht C, Verrelli N (eds) The federal idea: essays in honour of Ronald Watts. McGill-Queen's University Press, London, pp 169-187

United Nations Human Settlement Programme (2009) International guidelines on decentralisation and access to basic services for all. UN-Habitat, Nairobi

World Bank (1999) World development report 1999/2000: entering the 20th Century. World Bank, Washington DC 